\title{
ASSESSMENT OF THE EFFECTIVENESS OF INTERNAL CONTROL SYSTEM AND A CASE STUDY*
}

\author{
Arş. Gör. Alp AYTAÇa \\ Prof. Dr. Adem ÇABUK ${ }^{\mathrm{b}}$ \\ Muhasebe ve Vergi \\ Uygulamaları Dergisi \\ Temmuz, 2020; 13 (2): 353-376
}

Örnek Olay (Vak'a) Tahlili

(Case Analysis)

\begin{abstract}
Identifying risks and taking precautions should be taken into consideration for maintaining the activities. The negative effects of risks increase exponentially. In this risk determination and taking precaution process, internal control system holds a crucial position. Internal control system is affected by all stakeholders can ensure the reliability of financial statements, the protection of their assets and compliance with legal regulations. In this study, the change of internal control system from past to present have been put forward, the elements to be considered in the design and valuation process, and the problems encountered in this process are mentioned. Also, in order to compare the theoretical ground and its private sector application of internal control system, a company operating in Bursa, was selected by convenience sampling. In this study, semi-structured interview and document review method were used. Based on this, this company's strong and weak sides related to internal control system was put forward.
\end{abstract}

Keywords: Internal Control, COSO, Auditing, Case Study, Internal Control Effectiveness.

JEL Codes: M10, M40, M42.

APA Stili Kaynak Gösterimi:

Aytaç, A., Çabuk, A. (2020). Assessment of The Effectiveness of Internal Control System and A Case Study. Journal of Accounting and Taxation Studies. 13 (2), 353-376.

* Makalenin gönderim tarihi: 08.08.2019; Kabul tarihi: 13.02.2020, iThenticate benzerlik oranı \%19

${ }^{a}$ Uludağ Üniversitesi, İktisadi ve İdari Bilimler Fakültesi, alpaytac@uludag.edu.tr,

ORCID: 0000-0003-4949-4884.

${ }^{b}$ Uludağ Üniversitesi, Iktisadi ve İdari Bilimler Fakültesi, ademcabuk@uludag.edu.tr,

ORCID: 0000-0001-5463-8454.

Muhasebe ve Vergi Uygulamaları Dergisi 


\section{İÇ KONTROL SISTEMININ DEĞERLENDÍRILMESI VE BİR VAKA ANALIZi \\ ETKINLLİĞíNiN} öz

Risklerin belirlenmesi ve karşı önlemlerin alınması faaliyetlerin sürdürebilmesi açısından göz önünde bulundurulmalıdır. Risklerin olumsuz etkileri katlanarak artış göstermektedir. Risklerin belirlenmesi ve bunlara karşı önlem alınma sürecinde iç kontrol sistemi kritik bir noktada yer almaktadır. İç kontrol sistemi; tüm paydaşlardan etkilenen, finansal tabloların güvenilirliğini, varlıkların korunmasını ve yasal düzenlemelere uygunluğunu sağlamaktadır. Ele alınan çalışmada, iç kontrol sisteminin geçmişten günümüze değişimi, kurulum ve değerleme sürecinde dikkate alınması gereken faktörler ve bu süreçte karşılaşılan sorunlar ele alınmıştır. Ayrıca, iç kontrol sistemi ile ilgili teorik çerçevenin özel sektör uygulamalarındaki iç kontrol sistemi ile karşılaştırılması için Bursa'da faaliyet gösteren bir firma kolayda örnekleme yöntemiyle seçilmiştir. Bu çalışmada yarı yapılandırılmış görüşme ve doküman incelemesi yöntemi kullanılmıştır. Buna bağlı olarak firmanın iç kontrol sistemiyle ilgili güçlü ve zayıf yanları ortaya konulmuştur.

Anahtar Sözcükler: İç Kontrol, COSO, Denetim, Vaka Çalışması, İç Kontrolün Etkinliği.

JEL Kodları: M10, M40, M42.

\section{INTRODUCTION ${ }^{1}$}

Identifying risks and taking precautions should be taken into consideration for maintaining the activities. The negative effects of risks increase exponentially. In this risk determination and taking precaution process, internal control system holds a crucial position. Internal control applications are techniques for companies to compete under intense economic conditions. Internal control practices ensure that risks are predetermined and reveal possible opportunities and deficiencies for firms.

Measures should be taken in order to achieve specific goals and control activities measure the degree of achieved goals (Kaval, 2005: 4). The common objective of the audit activities provided by the Board of Directors is to increase the reliability of the enterprise by meeting the reliable information needs of both internal and external stakeholders and thus to maximize the company value.

Auditing is a systematic process of collecting, evaluating, and reporting to interested parties to determine the degree to which results of economic activities and events comply with predetermined criteria by independent persons (Güredin, 2010: Arens, Elder \& Beasley, 2012: Bozkurt, 2015: Yılanc1, Y1ldiz \& Kirac1, 2016).

Internal auditors are responsible within the company to make the auditing and they are first line of defense. They try to determine the extent to which

\footnotetext{
${ }^{1}$ This study was developed from the master's thesis entitled 'ASSESMENT THE EFFECTIVENESS OF INTERNAL CONTROL SYSTEM AND A CASE STUDY' which was accepted unanimously on 10.07.2014.
}

Muhasebe ve Vergi Uygulamaları Dergisi 
the tasks determined by the senior management are performed. According to Güredin (2010) "The purpose of internal audit is to investigate whether the business assets are protected against all kinds of losses, and the activities are carried out in accordance with the determined policies. The internal audit activity aims to measure the effectiveness of the controls in the enterprise and to evaluate these controls". In line with Güredin, according to Bozkurt (2015) the main activities of the internal auditors are "to investigate whether the business assets are adequately protected, to determine whether the accounting documents and information are reliable, to monitor the degree of compliance with the policies and procedures determined by the management of the company, to create an opinion on whether the business activities are effective and efficient, and to cooperate with independent auditors".

The auditing process can be outsourced or it can be provided from internal sources. The most important auditing tool provided from internal sources is "Internal Control System".

Rest of the paper is organized as follows: In the second section, development of the internal control is explained. In the third and fourth section design and evaluation of internal control system and the problems encountered in this process are explained. Fifth section is about the evaluation of the effectiveness of selected company's internal control system for the purpose of case study. Last section concludes the paper along with its limitations and future directions.

\section{DEVELOPMENT OF THE INTERNAL CONTROL SYSTEM}

Instantly changing economic conditions have increased the need for internal control systems. Some reports and regulations increased the awareness toward internal control system and made the world realize this fact. The most known of these reports and regulations about the internal control system are; COSO, CoCo, Sarbanes-Oxley Act, INTOSAI and Turnbull Report.

Committee of Sponsoring Organizations of the Treadway Committee (COSO) released the Internal Control-Integrated Framework (main framework) in 1992. This framework has been widely accepted and used throughout the world. The text was accepted and adopted as a guiding framework in the design, implementation and performing of internal control and in evaluating the effectiveness of internal control (Türkiye İç Denetim Enstitüsü Yayınları, 2016).

CoCo is another which aimed to increase control. The report includes the definition of control and the criteria for effective control in firms. In the CoCo report, the components consist of purpose, commitment, capability, monitoring and learning (CoCo, 1995). 
Due to corporate scandals, Sarbanes-Oxley Act was accepted at the United States Congress on 2002. Corporate scandals such as Enron and WorldCom cause great damage to the market. The common points of these scandals are senior management bent the rules, inadequate internal control structure, inadequate independent auditing, failure to comply with segregation of duties etc. Sarbanes-Oxley Act effected internal and external auditors, senior management and other interested parties and cause internal auditing to gain legal applicability (Moeller, 2014, p. xi).

The growing importance of internal control system which is started by COSO report, was also stressed at the 17th INTOSAI meeting held in Seoul in 2001. The action plan came to the agenda at the 50th meeting in Vienna on October 2002 and was accepted. During the meeting held in Brussels on February 2004, the draft was discussed and generally accepted. The purpose of preparing the report is to develop guidelines for the establishment and continuity of effective internal control for the public sector. Using this guide helps public administrators to establish the infrastructure for the establishment and operation of internal control in their own institutions (INTOSAI, 2004, pp. 1-2).

Another international report which is The Turnbull Report was first published in 1999 and set out best practice on internal control for UK listed companies. On October 2005 the Financial Reporting Council (FRC) issued an updated version of the guidance with the title "Internal Control: Guidance for Directors on the Combined Code" (www.governance.co.uk, 19.12.2016).

Besides international reports and regulations, also domestic regulations about internal control system have been made. Regulations related to the internal control system in the public sector in Turkey are discussed in the framework of the Public Financial System and Control Act of 5018. Within the framework of this law, articles 55-62 of Section 5 contain definitions related to internal control. In these articles, the purpose, structure and functioning of the system are explained. Also, who is in charge and what are the duties and responsibilities of this person is explained. (www.mevzuat.gov.tr).

The importance of internal control has been increasing exponentially with the realization of international and domestic reports and regulations. The emergence of the internal control system and the increase in its importance stem from events that occurred in the past. These events caused great damage to both companies and countries and thus brought corporate identity to the fore. The most important of these events are Barings Bank, Daiwa Bank, Allied Irish Bank, Societe Generale, Enron and Anderson, WorldCom and Parmalat. The common point of these events is that they do not comply with the general requirements of the internal control systems. This situation

Muhasebe ve Vergi Uygulamaları Dergisi 
increases the likelihood of fraudulent events. In an ineffective internal control system where employees have a chance to hide fraudulent activities, more serious events occurred. Consequently, in these cases, some companies suffered from great losses and others face bankruptcy.

The circumstances and the events experienced have led the countries to address different aspects of the system given in the definition of internal control. In this study, COSO's internal control definition is used because it covers both the private and public sectors. Also, Turkey, where the case study took place, has integrated the COSO's internal control definition into its regulation. According to COSO Report, internal control is defined, "as a process, effected by an entity's board of directors, management and other personnel, designed to provide reasonable assurance of the achievement of objectives such as effectiveness and efficiency of operations, reliability of financial reporting and compliance with applicable laws and regulations" (Türkiye İç Denetim Enstitüsü Yayınları, 2016).

In order to achieve the goals of an effective internal control system in the COSO Report, the system must be designed and evaluated properly. The design and evaluation process is the nucleus of an effective and efficient internal control system. In the next section, these processes are explained in detail.

\section{DESIGN AND EVALUATION PROCESS}

The design of the internal control system is crucial for the effective operation and supervision of this system. To ensure the design of internal control, the system must be built on strong foundations. The COSO Report, which forms the basis of internal control, deals with the components of this system.

According to the COSO Report, there are 5 components of the internal control system which are; (1) control environment, (2) risk assessment, (3) control activities, (4) information and communication and (5) monitoring. The framework sets forth seventeen principles that demonstrate both the five components of internal control and the basic concepts associated with these components. In the COSO report, (1) control environment is the set of standards, processes and structures that constitute the basis for the internal control to be carried out throughout the organization. (2) Risk assessment covers a dynamic and iterative process that identifies and analyzes the risks for achieving the objectives of the organization and provides a basis for how these risks should be managed. (3) Control activities are actions determined by policies and procedures that help ensure the implementation of the instructions to reduce the risks for achieving the objectives. It is within the (4) information and communication component that the organization needs 
information to perform its internal control responsibilities in a way that supports the achievement of its objectives and provides the employees with both internal control responsibilities and their understanding of the importance of these responsibilities in reaching their goals through communication. (5) Monitoring is to determine whether each of the five components of internal control, including controls affecting the principles within each of the internal control components, is present and in operation (Türkiye İç Denetim Enstitüsü Yayınları, 2016). The following figure shows which sub-principles are in relation to the five components of internal control.

Figure-1: COSO Components Principles

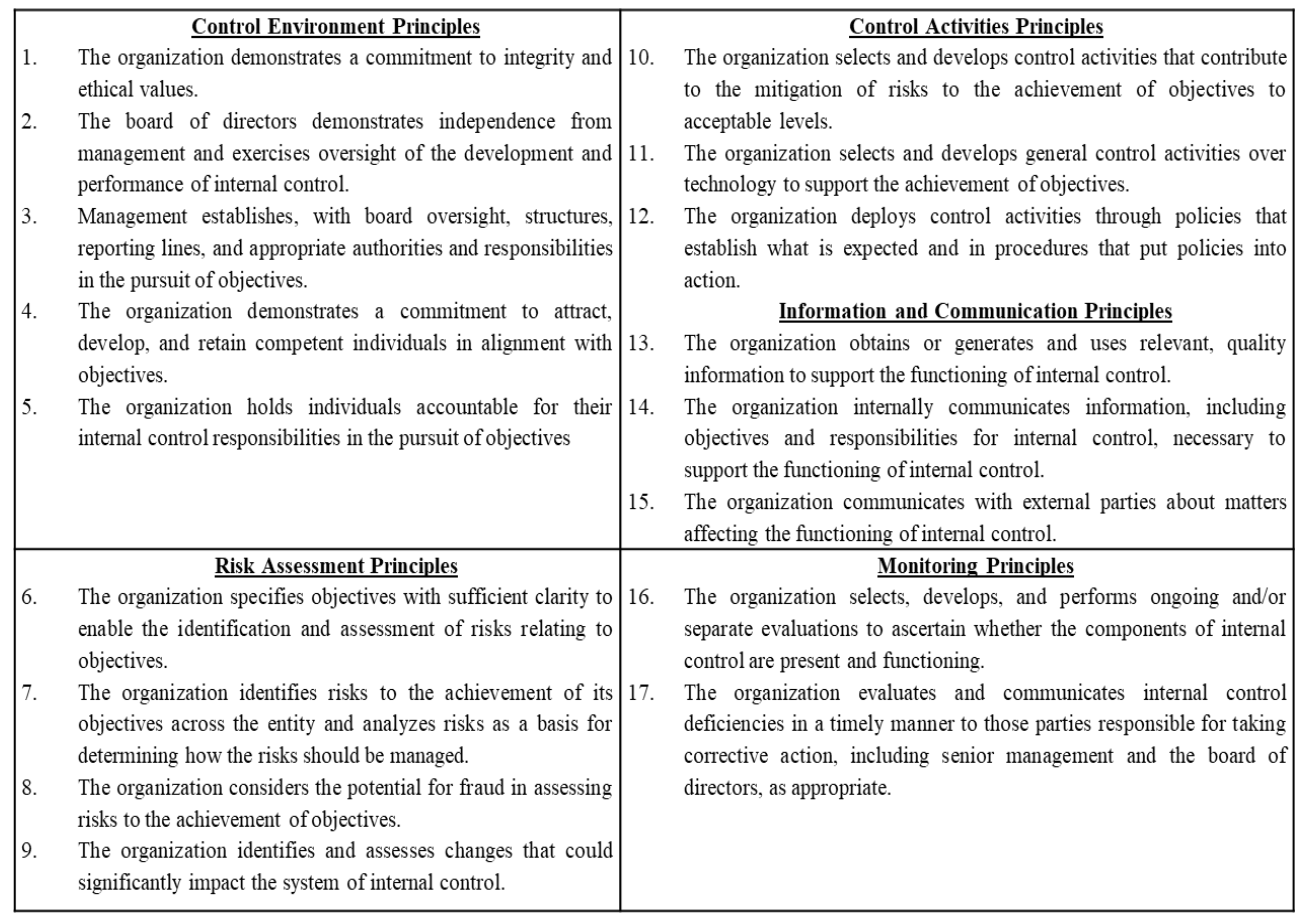

Source: Türkiye İç Denetim Enstitüsü Yayınları (2016), İç Kontrol Bütünleşik Çerçeve: Çerçeve ve Ekler, 1.Baskı, İstanbul

The essential factors in the efficient functioning of the components of the COSO Report are employee participation, qualification and intention. Even if the standards of the system appropriately designed, the lack of qualified employees required for the protection and development of the system, the failure to give the necessary importance to the system, employee intention on the error and the fraud, will undermine the operation of the control mechanism and will cause harm to the companies. For these reasons, each individual who is in relation with the company within the internal control system has a responsibility and everyone must completely fulfill these responsibilities. The operation of the internal control system requires the 
active participation of the main actors. These actors are; Board of Directors, senior management, audit committee, employees and independent auditors. Board of Directors, senior management, audit committee and employees are the main actors inside the company. Board of Directors is responsible for the establishment and development of the internal control system. Under the leadership of the Board of Directors, all internal stakeholders play a crucial role in ensuring the functioning of the system.

Proper installation of the internal control system and making its sustainability is fragile. This system, as mentioned in the COSO Report, is affected by many factors. The main factors that influence are; organizational structure, distribution of authority and responsibility, independent evaluation, separation of duties, proper installation of communication channels, risk identification, etc.

Organizational structure is a critical factor in the internal control system. This structure is a foundation of what the company will do and how it will be accomplished. In the design and analysis stage of the organizational structure division of labor and specialization, authority structure and degree of centralization, degree of complexity, the extent of control area, degree of formalization and degree of division should be considered. Organizational structure may vary depends according to the companies' characteristics and sectors they operate. This structure holds is an important element in ensuring the control activities and providing auditing (Moeller, 2004: Efil, 2005).

In the distribution of authority and responsibility, the knowledge and skills of the employees, their experience in business, their reactions to the risks they face should be carefully analyzed and distributed. As soon as the authorized and responsible employees are clearly identified, the transactions are determined and the necessary measures are taken quickly.

Internal control system is also analyzed by independent auditors. In the auditing process, the auditors try to identify the effectiveness of the system. Based on this, auditors try to evaluate the auditing risk they will face. Independent auditors can provide different perspectives on the internal control system, shed light on the deficiencies of the system and cause solution suggestions for their removal.

During the phase of reviewing the internal control structure, auditors must adequately recognize the internal control environment, accounting system, control procedures, risk evaluation processes, management's and personnel's perception of internal control and workflows. Auditor's main aim for reviewing the internal control structure is to identify control risk in the determination of auditing risk. Identifying control risk is part of the process for preparing audit programs. (Güredin, 2010: Bozkurt, 2015: Y1lanc1, Y1ldız \& Kirac1, 2016). 
In short, the control environment is an effective component in the design of the internal control system because it is the infrastructure of the system. The internal control system is like a wheel, and the control environment is the infrastructure of this wheel. Even if all the components are operating properly if the foundation is damaged, then all other components are affected negatively and the wheel can break. For this reason, in the design stage, procedures about the control environment should be carried out cautiously.

After making a solid foundation, identifying risks is the second phase in the design process. In this process, the segregation of duties, proper installation of communication channels makes the risk identification timely and reliable.

Segregation of duties is useful in the risk assessment phase and therefore in the design of the internal control system. In the course of a workflow, no employee should be present as the sole authority until the end. In the presence of such a situation, the probability of fraud becomes stronger. By applying this, companies can create an auto-control mechanism. Because in the segregation of duties, each employee is responsible for single work in the workflow. Thus, every responsible employee controls the work that comes before (Bozkurt, 2016, p. 119: Y1lanc1, Y1ld1z \& Kirac1, 2016, pp. 128-129). It is not enough to match the principle of separation of duties only with the risk assessment standard. This principle plays a vital role in the standard of control activities as well.

The establishment of the control environment and risk assessment processes separately is not sufficient for the design of the internal control system. To ensure the effectiveness of this system, timely and appropriate communication is required. The proper installation of the communication channels and the timely provision of the information needed are the essential tools used in the control mechanism. There is a close relationship between organizational structure and communication channels.

COSO components are taken as a whole. Separate functioning of the components creates value, but when working as a whole, the outcome is much more than the individual result. Also, deficiency in the one component affects others as well. Components of the systems do not give the desired result on their own. For this reason, is crucial that the system must work as a whole. When there is a deficiency in the system's operation, precautions should be taken and the root cause should be solved immediately.

Muhasebe ve Vergi Uygulamaları Dergisi 


\section{PROBLEMS ENCOUNTERED IN THE DESIGN AND EVALUATION PROCESS}

Internal control system brings many advantages to the companies. For instance, it increases the value of the financial reports submitted by the firms in the view of the stakeholders, ensures the protection of the most important items of the companies to sustain their activities and ensures compliance with the regulations brought by the legal environment within the important stakeholders. Although the operation of the system provides significant advantages to the companies, there are substantial obstacles to the proper functioning of the system. In the internal control system, if uncorrected errors affected the reliability of financial statements, they are called "material weakness". Auditors are responsible for determining whether errors are material or not. Examples of material weaknesses are failure to reconcile certain general ledger accounts on a timely and regular basis and lack of management review of certain reconciliations, inconsistent application of accounting policies, including capitalization policies and procedures for determining unrecorded liabilities, failure of financial management in certain operating segments to properly supervise personnel, enforce and follow policies and procedures, and perform their assigned duties, lack of adequately staffed accounting departments, lacking of key control activities, unable to apply segregation of duties, failure to protect valuable assets etc. (Doyle, Ge \& McVay, 2007: Arens, Elder \& Beasley, 2012). According to Kaval (2005), the internal control structure of a business is particularly affected by "the size of the enterprise, the ownership structure, the sector in operation, the quality of the information communication system used and the legal regulations". As the size of the business grows and the sector becomes more complex, it becomes difficult for the internal control system to function effectively. On the other hand, increasing the quality of the information communication system and ensuring a high degree of compliance with legal regulations will contribute positively to the effectiveness of internal control.

Making public disclosure is another obstacle in ensuring an effective internal control system. Making internal control deficiency disclosure (ICD) may cast doubt on the reliability of financial statements. This situation arises criticism from the market and firm's cost of capital and profitability ratios affected negatively. Besides, management's reputation and potential investors' decisions affected negatively. However, if there is a new management change, this management will disclose ICD's without hesitation because the responsibility of this ICD's lies on the predecessor management (Ashbaugh-Skaife, Collins \& Kinney, 2006, p. 189).

To make the internal control system work effectively and efficiently, a structure that conforms to the components and criteria in the COSO Report 
should be established and the risks should be minimized for the operation of this structure.

\section{CASE STUDY TOWARD THE INVESTIGATION AND EVALUATION ON INTERNAL CONTROL SYSTEM}

\subsection{Aim of the Study}

This study aims to determine whether the requirements of the internal control system are fulfilled in the private sector by case study method and to show the strong and weak sides of the internal control system of the selected company. In the auditing literature, some studies that examine the effectiveness of the COSO based internal control system. Ünkaya and Dursun (2018), examine the use of whistleblowing to increase the effectiveness of the system while Coşkun and Teraman (2018) interviewed with auditors to shed light the effectiveness COSO based system. Gökçen and Tipi (2019) made a research to show the influence of the internal control system towards preventing potential frauds in manufacturing that operates in BIST.

Also, in this study, it is aimed to determine to what extent the theoretical framework of the internal control system corresponds to a case in the practical field. By accomplishing these aims, the authors contribute to the auditing field by revealing the theoretical framework application degree of an internal control system in a case study.

\subsection{Scope of the study}

In this study, the effectiveness of $\mathrm{ABC}^{2}$ Company's current control structure is evaluated. $\mathrm{ABC}$ Company operates in a private sector in Bursa, and they produce air springs. The ABC Company selected through convenience sampling method.

\subsection{Data Collection}

In this study, the authors used case-study, semi-structured interview, and document review techniques to evaluate the efficacy of the internal control system.

The case study is a systematic process of research beyond formal constitutions and formal structures in a specific context about one or more organizations or groups (Zainal, 2007: Magrane and Malthus, 2010: Altunışık et al., 2012).

The case study method used in the auditing field because of this method contains primary data and shows the actual situation of the selected companies. In Arena et al.'s (2006) study, authors carried out a multiple

\footnotetext{
${ }^{2}$ In this study, real name of the company is not mentioned due to confidentiality agreement. For this reason, the name of the company is used as ABC Company.
}

Muhasebe ve Vergi Uygulamaları Dergisi 
case study that compares the Internal Audit Departments of six Italian companies, gathering evidence by interviews with chief internal auditors, by obtaining examples of internal audit reports, policy documents and corporate briefing notes. Also, Getie Mihret and Wondim Yishaw (2007) based their study upon a case study of a large public sector higher educational institution in Ethiopia, examine how internal audit quality, management support, organizational setting, auditee attributes, and the interplay among these factors, influence internal audit effectiveness. Besides, Gethie Mihret and Zemanu Woldeyohannis (2008), Chen et al. (2010), Magrane and Malthus (2010) and Aslan (2019) based their studies upon a case study method. Aslan (2019) examined the necessity and importance of the internal control system in the case of Enron. Also, Özçetin and Uzay (2018) used primary data in their study. The authors tried to evaluate the internal control system effectiveness at dairies and compare their results with Brazilian companies. They did surveys with top managers to obtain primary data to draw reliable conclusions.

In the data collection phase, semi-structured interview technique was used. To gather detailed information about the internal control system of the $\mathrm{ABC}$ Company, the authors chose flexible questions in the interview. According to Merriam (2013), "this format allows the researcher to respond to the situation at hand, to the emerging worldview of the respondent, and new ideas on the topic". In this context, interviews made with the administrative affairs \& finance manager and quality manager of the ABC Company and detailed information collected about the company. Also, these managers provide documents about the company as well. Akın and Güngör Tanç (2019) also used a semi-structured interview to examine the internal control system in the process of export operations. They did interviews with customs brokers and export experts of companies.

Along with a case study and semi-structured interviews, the document review method used in the study as well. "Document review covers the analysis of written materials containing information about the cases or facts intended to be investigated. In qualitative research, document review can be used together with other data collection methods. In this respect, the combination of interview and document review serve the purpose of diversifying the data and contributes to the validity of the research" (Yıldırım and Şimşek, 2013, pp. 217-220). Based on this, conducting a document review along with semi-structured interviews in a case strengthens the validity of this research.

\subsection{Information About the ABC Company}

ABC Company began producing air springs in Bursa in 1986. It mainly operates in the key and subsidiary automotive industry sectors, along with agricultural machinery and vehicles, industrial applications, railway 
systems, and construction applications sectors where air springs are utilized effectively; and is currently exporting over 1200 types of products to more than 80 countries in 5 continents, with production facilities in 2 different locations in Turkey and delivery channels in 4 different locations including USA and Europe. It carries out all its productions under ISO/TS 16949, ISO 9001, ISO 14001, and OHSAS 18001 quality standards, and produces highly durable and long-lasting air springs for heavy vehicles, trucks, tractors, buses and trailers.

\subsection{Evaluation of ABC Company's Current Internal Control Structure}

In this study, based on document review and semi-structured interview in $\mathrm{ABC}$ Company, the authors tried to evaluate the effectiveness of $\mathrm{ABC}$ Company's internal control system. Based on the methods used, evaluations are divided into 4 main topics which are: quality standards, organizational chart, proper job description, and delegation of authority.

\subsubsection{Quality Standards}

Conducting the activities in line with quality standards is an indication that internal control activities take place. To have a quality certificate, the activities must be carried out in accordance with the desired standards. This means all the activities should be made correctly and if there is a difference in what is being done and what should be done, preventative actions should take place.

ABC Company has quality standards such as ISO/TS 16949, ISO 9001, ISO 14001, and OHSAS 18001, and this is an essential clue for internal control structure. In addition, to ensure institutionalism, transparency, and control system in the company, the objectives, vision, mission, as well as honesty, responsibility, product reliability, high quality, efficiency, customer orientation principles, are adopted and the goals are clearly stated on the company's web site. The adoption of these criteria by the company and the public disclosure of them is an indication of institutionalism and all the activities will be aimed at realizing these goals. In case of exceeding the determined targets, the control mechanism will be activated and the necessary precautions will be taken.

The fact that the ABC Company has quality certificates causes the audit work to be carried out intensively within the company. As a result of the interviews conducted with the quality manager, it was learnt that the external audit had been conducted once a year for the quality audit and certification audit has been done in every two years. Internal audit, process and general audits are also carried out by the company's personnel. In the process audit, examinations are made as to whether the works are performed correctly or not under the quality standards. In the overall audit, all departments are examined. The process control carries out the system's

Muhasebe ve Vergi Uygulamaları Dergisi 
functionality and whether there are errors in the system. These reports include suggestions for solving mistakes. The principle of limitation of access also applies here. Reports are published electronically over a public network. The other studies related to the audit are performed by the certified public accountants (CPA). The financial statements of the company are prepared by the CPA's who act as their personnel and the documents are kept within the company. Control activities and observation standards are effectively used in the internal control system as an indicator of all these situations. The main reason for this is that the company's activities are carried out under the quality standards.

Kara's (2019) study shows the effect of quality management system certificate to internal control system. In this study, Kara investigated whether there is a difference between the effectiveness of the companies that have a quality management certificate with the support of the consultant or their own quality management team. As a result of the results, it is concluded that the companies that have quality management certificate with the support of the consultant are more effective in the control environment, control activities, risk valuation and information and communication headings, but there is no statistical difference in terms of monitoring activities. Overall, these results indicate that having a quality management certificate effects internal control system effectiveness. This result supports the conclusion that "conducting the activities in line with quality standards is an indication that internal control activities take place" at ABC Company.

\subsubsection{Organizational Chart}

Having an organizational chart and public disclosure of it adds value to the internal control system's effectiveness. ABC Company has a detailed organizational chart. This shows that the boundaries of the internal workflows of the company are plotted and it is an added value for the internal control system. The organizational chart of the ABC Company can be seen in Figure 2. 
Figure-2: Organizational Chart of the ABC Company

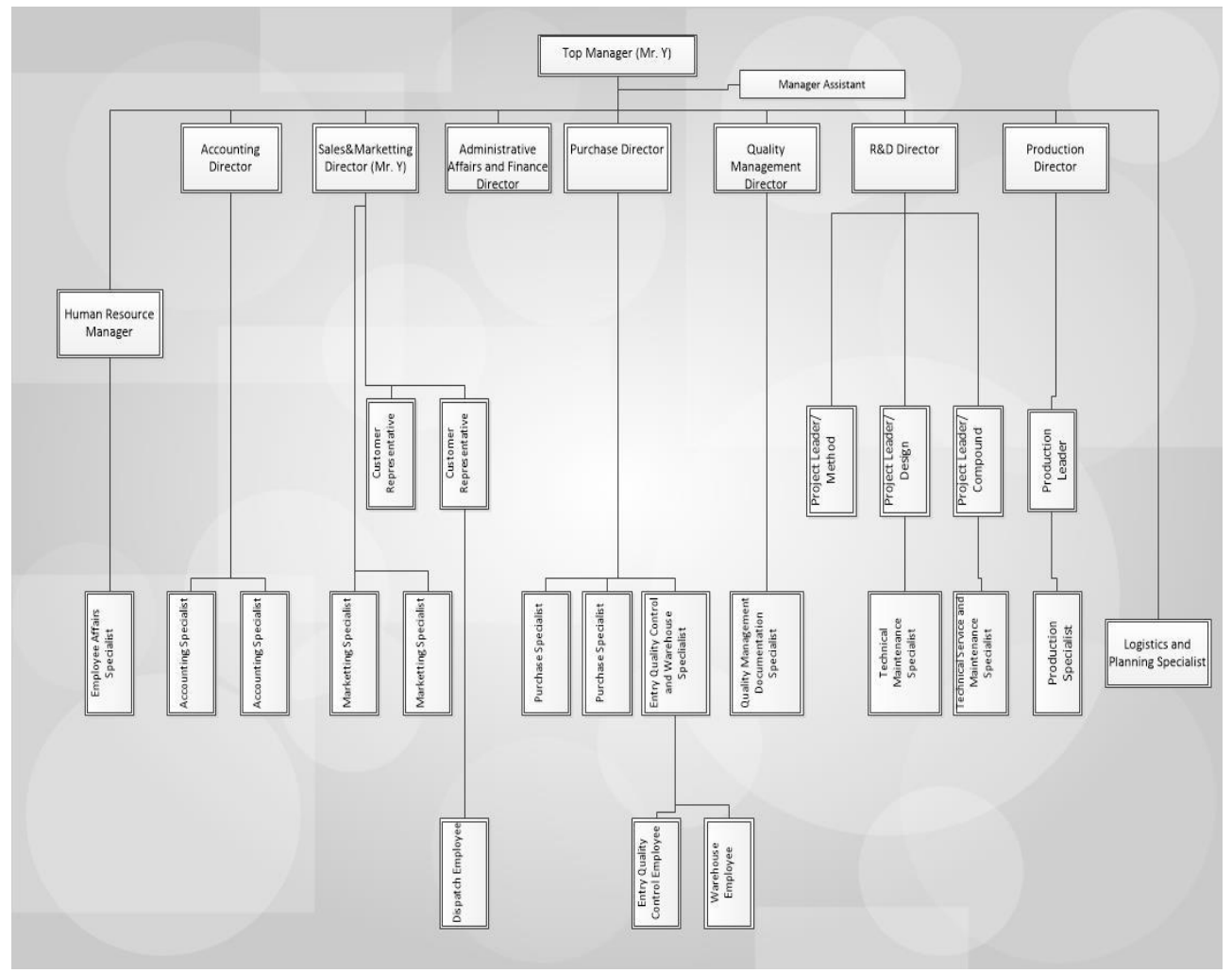

When looking at the organizational chart, it is observed that it has a structure required by the internal control system hierarchically. When the hierarchical places of senior executives examined, it is seen that there is no specialist on the same level as managers. However, the presence of a single employee in the administrative affairs and finance department of such a large firm is contrary to the internal control system. When the requirements of the internal control system considered, it is emphasized that a single employee is not authorized from the beginning to the end of any process, and segregation of duties is required. A negative situation arises in the finance department because there is one employee who has the authority and responsibility to do all the activities and transactions related to this department. In such a case, the detection of erroneous and fraudulent transactions becomes difficult. Although all managers depend on top management, the fact that no additional employee works for the finance department creates a negative situation for the firm's existing internal control structure.

Considering the company's characteristics and organizational chart, the company that sells high rates of goods abroad and does not have an import and export department. The sales and marketing manager seems to have gathered both domestic and international transactions. This situation may overload sales and marketing manager's work.

Muhasebe ve Vergi Uygulamaları Dergisi 
The logistics department has an essential place in the company's working with foreign countries. The logistics department ensures that the needs of the customers met on time. There must be a logistics and planning manager within the company to ensure that the product is sold in accordance with customer requirements. Considering the organization chart for the $\mathrm{ABC}$ Company, there is only one employee for this department and he is also in charge of the responsible position. The adverse situation stated for the finance department is also valid for this department. In addition, the authority and responsibility of the sole employee in the department are also one of the missing aspects of the control system.

The fact that the top responsible for human resources is not in the same line with managers is a negative situation for the internal control system. It is a negative situation that this employee is at a level between the manager and specialist. Because ABC Company operates abroad as well and human resources is a significant element in the internal control system. In such a large firm, this department should be represented at the highest level to hire suitable candidates within the framework of the company's culture and internal control system.

The internal control system requires that no employee should be in charge from the beginning to the end of any transactions. Also, no employee should not have the authority and responsibility of more than one department. Considering the organizational chart, Mr. Y who is the top manager of the $\mathrm{ABC}$ Company, responsible for the company's operation as well as the Sales and Marketing Department. The existing situation causes the authorities and responsibilities to be intertwined. As a result, it indicates an adverse condition for the internal control system.

\subsubsection{Proper Job Description}

In the internal control system, proper job description means that duties and responsibilities should match. In the study, the information obtained from the company includes job descriptions for the accounting department. Within the organizational chart, the accounting department consists of one manager and two specialists. Figure 3 and 4 show the job descriptions of the accounting manager and specialists for the ABC Company: 
Figure-3: Accounting Manager Fundamental Duties and Responsibilities

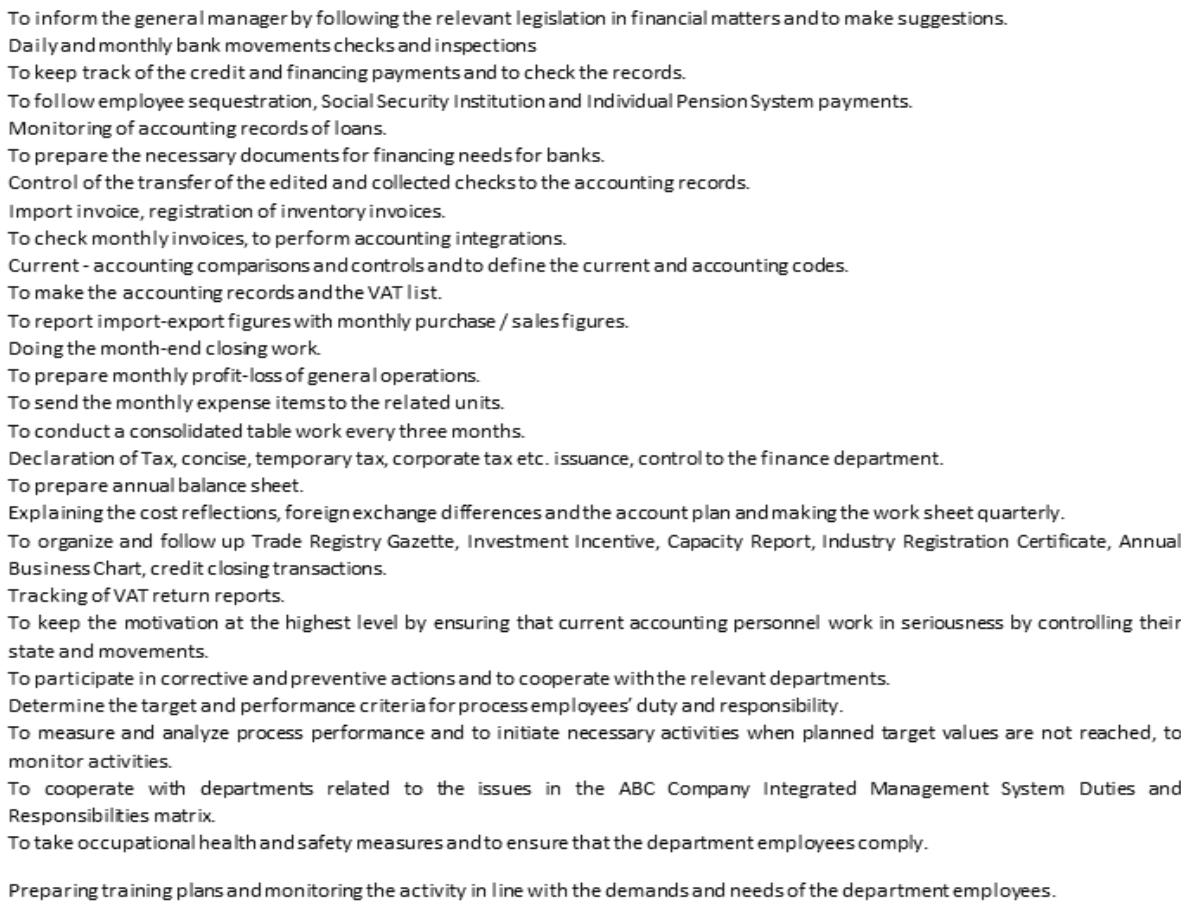

Figure-4: Accounting Specialist Fundamental Duties and Responsibilities

1. Perform control by accounting for purchase and sales invoices.

2. To process supplier payments.

3. To report weekly supplier balances.

4. Control of insurance policies.

5. Control of VAT list and comparison with accounting.

6. To close the monthly exchange rate differences of the suppliers.

7. To follow the Plant Machine and Asset List and to inform the new ones.

8. Processing of bank account statements.

9. Keeping the motivation of current accounting personnel to work in seriousness by controlling their behavior and state.

10. Supporting accounting and finance

11. To participate in corrective and preventive actions and to cooperate with all relevant departments.

12. To act according to Occupational Health and Safety instructions.

13. To perform other duties assigned by the Head of Section and to participate in training and activities.

14. To promote waste management by participating in the collection and separation of waste.

15. To participate in risk analysis studies and to follow the action plans.

16. To take part in activities that will keep the occupational safety at the maximum level.

When the job descriptions of the accounting manager and the accounting specialist examined, it was determined that these descriptions are not intertwined, and thus this shows a positive situation for the internal control system. Also, the accounting manager's job description within the framework of the follow-up of the work is an indicator of the existence of continuous control. As a result, necessary control mechanisms will be provided for the detection of faulty and/or fraudulent transactions.

Muhasebe ve Vergi Uygulamaları Dergisi 
When the job descriptions of both employees are examined, participating in corrective and preventive activities is an essential value for the internal control system. As a result of face-to-face interviews conducted with the Quality Manager of ABC Company, it was determined that corrective and preventive actions are applied if a problem occurs in workflows. The nature of the job and the answers given according to the level of importance vary. Within the Company, preventive activities are taken for the problems arising within the workflows. This is especially used in the production section but it is tried to be applied in the same way for other departments. To apply preventive activities, the root cause of the problem tried to be reached and necessary actions are carried out to prevent the repetition of the problem. The participation of all departments in these studies is among the factors that increase the efficiency of the internal control system to ensure the widespread application and to create different ideas.

The quarterly consolidated statements of the accounting manager and the trial balance also included in the control activities. In this way, the compliance of the transactions is determined.

Among the job descriptions within the accounting department, taking part in the required training according to the quality standards is one of the procedures to be followed in the internal control system. Continuing education provides the development of staff and helps to gain the relevant practice. As a requirement of quality standards, they perform their business under these objectives. Conducting the work done to specific standards also facilitates the control of the work. In case of not complying with the standards, necessary precautions were taken immediately.

In the accounting specialist's job description, disseminating the waste collection activities and making them widespread within the company is a factor that ensures environmental sustainability. Necessary works are carried out in accordance with the Environmental Standards owned by the company and efforts are made to ensure the effectiveness of the resources. One of the factors involved in the definition of the internal control system is the provision of resource efficiency in the company. The studies aimed at realizing this purpose.

One of the crucial components of the internal control system is risk assessment. In the risk assessment process, the risks that the enterprise faced will be determined and the degrees of effect will be reduced and if possible, the risks tried to transform into opportunities. Among the job descriptions of the accountant is to participate in the risk analysis studies, and to follow up the action plans. In this way, risk studies carried out within the company and follow-up of the transactions will be provided. As a result, work flow under the standards required by the control system will be made. 
As part of the case study, the job description of the Administrative Affairs and Finance Manager was obtained. On figure 5, the job description of this manager can be seen.

Figure-5: Job Description of Administrative Affairs and Finance Manager

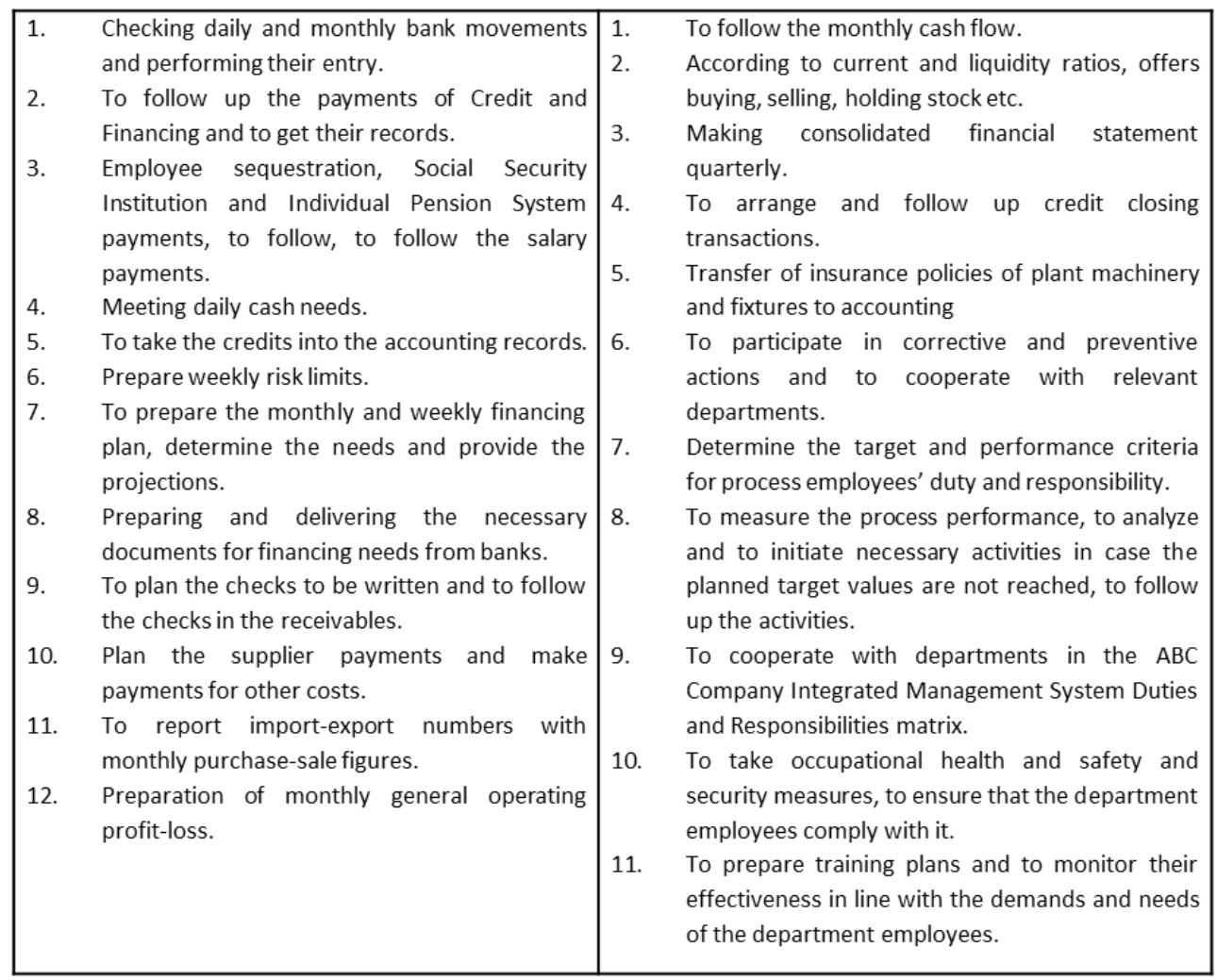

The finance department is one of the most important departments in terms of providing efficiency and effectiveness while meeting the commercial activities of enterprises. It is expected that there will be more than one employee naturally, and there will be differences in job descriptions. As mentioned earlier, only an employee is employed in the department of administrative affairs and finance of the company, and he has been doing all the work related to the department from the beginning to the end. When the job descriptions are examined, "Checking daily and monthly bank movements and performing their journal entries" creates a negative situation for the internal control system. Leaving the bank account entries' authority and responsibility of a person increases the likelihood of error and fraud and makes it difficult to determine the situation in case of occurrence of fraudulent transactions. Administrative affairs and finance manager also set weekly risk limits. This duty is not among the duties and responsibilities of the accounting manager. If the preparation of the weekly risk limits were prepared by both the accounting manager and the administrative affairs and finance manager together, a practical result would have been obtained for

Muhasebe ve Vergi Uygulamaları Dergisi 
the internal control system and at the same time, a suitable situation would have been made for the principle of segregation of duties.

\subsubsection{Delegation of Authority}

In the scope of the study, the delegation of authority is evaluated. Delegation of Authority table of ABC Company can be seen in Figure 6.

Figure-6: Delegation of Authority Table of ABC Company

\begin{tabular}{|c|c|c|c|}
\hline DUTY & AUTHORIZED & $\begin{array}{c}\text { DELEGATION OF AUTHORITY } \\
1^{\text {ST }} \text { PERSON }\end{array}$ & $\begin{array}{c}\text { DELEGATION OF AUTHORITY } \\
2^{\text {ND PERSON }}\end{array}$ \\
\hline General Manager & General Manager & $\begin{array}{l}\text { Production Group Manager } \\
\text { (Excluding Commercial and } \\
\text { Financial Activities) }\end{array}$ & $\begin{array}{l}\text { Administrative Affairs and } \\
\text { Finance Manager }\end{array}$ \\
\hline Production Group Manager & Production Group Manager & General Manager & \\
\hline Commercial Group Manager & General Manager & & \\
\hline Quality Management Manager & Quality Management Manager & General Manager & \\
\hline $\begin{array}{l}\text { Administrative Affairs and } \\
\text { Finance Manager }\end{array}$ & $\begin{array}{l}\text { Administrative Affairs and } \\
\text { Finance Manager }\end{array}$ & General Manager & \\
\hline Sales - Marketing Manager & $\begin{array}{l}\text { Sales - Marketing Manager ( } \\
\text { General Manager) }\end{array}$ & Customer Representative & Customer Representative \\
\hline Accounting Manager & Accounting Manager & General Manager & \\
\hline Production Manager & Production Manager & Production Group Manager & \\
\hline Production Specialist & Production Specialist & Production Leader & \\
\hline $\begin{array}{l}\text { Logistics and Planning } \\
\text { Specialist }\end{array}$ & $\begin{array}{l}\text { Logistics and Planning } \\
\text { Specialist }\end{array}$ & $\begin{array}{l}\text { Production Planning } \\
\text { Specialist }\end{array}$ & \\
\hline R\&D Manager & R\&D Manager & Production Manager & Project Leader (Method) \\
\hline Project Leader (Design) & Project Leader (Design) & R\&D Manager & \\
\hline $\begin{array}{l}\text { Project Leader (Product } \\
\text { Compound) }\end{array}$ & $\begin{array}{l}\text { Project Leader (Product } \\
\text { Compound) }\end{array}$ & R\&D Manager & Project Leader (Design) \\
\hline Project Leader (Method) & Project Leader (Method) & R\&D Manager & \\
\hline $\begin{array}{l}\text { Technical Service and Maintenance } \\
\text { Specialist }\end{array}$ & $\begin{array}{l}\text { Technical Service and } \\
\text { Maintenance Specialist }\end{array}$ & $\begin{array}{l}\text { Production Planning } \\
\text { Specialist }\end{array}$ & Project Leader (Method) \\
\hline Technical Supervisor & Technical Supervisor & Project Leader (Design) & \\
\hline $\begin{array}{l}\text { Quality Management } \\
\text { Documentation Specialist }\end{array}$ & $\begin{array}{l}\text { Quality Management } \\
\text { Documentation Specialist }\end{array}$ & $\begin{array}{l}\text { Quality Management } \\
\text { Manager }\end{array}$ & \\
\hline Purchase Manager & Purchase Manager & General Manager & Purchase Specialist \\
\hline Purchase Specialist & Purchase Specialist & Purchase Manager & Purchase Specialist \\
\hline Purchase Specialist & Purchase Specialist & Purchase Manager & Purchase Specialist \\
\hline $\begin{array}{l}\text { Entry Quality Control and Warehouse } \\
\text { Specialist }\end{array}$ & $\begin{array}{l}\text { Entry Quality Control and } \\
\text { Warehouse Specialist }\end{array}$ & Entry Quality Control Employee & Warehouse Personnel \\
\hline Entry Quality Control Employee & $\begin{array}{l}\text { Entry Quality Control } \\
\text { Employee }\end{array}$ & $\begin{array}{l}\text { Entry Quality Control and } \\
\text { Warehouse Specialist }\end{array}$ & Warehouse Personnel \\
\hline Warehouse Personnel & Warehouse Personnel & Entry Quality Control Employee & $\begin{array}{l}\text { Entry Quality Control and } \\
\text { Warehouse Specialist }\end{array}$ \\
\hline $\begin{array}{l}\text { Sales - Marketing } \\
\text { Specialist }\end{array}$ & $\begin{array}{l}\text { Sales-Marketing } \\
\text { Specialist }\end{array}$ & Customer Representative & \\
\hline $\begin{array}{l}\text { Sales - Marketing } \\
\text { Specialist }\end{array}$ & $\begin{array}{l}\text { Sales-Marketing } \\
\text { Specialist }\end{array}$ & $\begin{array}{l}\text { Sales-Marketing } \\
\text { Specialist }\end{array}$ & Customer Representative \\
\hline Customer Representative & Customer Representative & Customer Representative & $\begin{array}{l}\text { Sales - Marketing } \\
\text { specialist }\end{array}$ \\
\hline
\end{tabular}

Having a delegation of authority table is a factor that increases the effectiveness of the internal control system. Continuity of the activities should be ensured in case of emergencies or where employees are on leave. For this reason, if an employee cannot be on duty with such excuses, another employee with his authority should ensure the continuity of the operations. The fact that ABC Company has this table shows the importance they give to the continuity of activities and it is a necessity for the internal control system to ensure transparency and continuity.

When comparing the organizational chart and delegation of authority table of the ABC Company, it was detected that some deficiencies arise. On the delegation of authority table, production group manager, commercial group

Muhasebe ve Vergi Uygulamaları Dergisi 
manager and sales-marketing specialists are included but not included in the organizational chart. This indicates a negative situation for the internal control system because key roles in the delegation of authority tables are not mentioned in the organizational chart.

\subsection{Discussion}

The ABC Company applies its internal control activities intensively and has an essential position in the market. It is not possible to say that the firm has fully implemented the requirements of the internal control system. Considering the organizational chart, job descriptions and delegation of authority table, there are significant deficiencies in the standards. The factors affect on this result are listed below;

- Lacking risk assessment department,

- Significant exposure to the risk of error and fraud as the principle of segregation of duties is not carried out properly,

- There is no organizational chart in accordance with the structure of the company,

- There is a mismatch between the delegation of authority and the organizational chart,

- Lack of a separate internal control unit.

In case of the existence of factors not supporting the internal control system, the presence of crucial factors that adds value to the internal control system does exist. The importance is given by the ABC Company to quality activities significantly affects the functioning of the system. The fact that both internal control and external auditing activities are carried out intensively for quality certification, and the presence of the delegation of authority shows that the control activities and monitoring are fulfilled from the standards. The information and communication standard is provided electronically within the company and the information reaches the desired department quickly. Risk assessment activities distributed among departments. The functioning of the system generally provided within the $\mathrm{ABC}$ Company despite deficiencies. If the shortcomings eliminated, the probability of experiencing errors and frauds reduced significantly and the targets determined according to the quality standards will be reached easily.

\section{CONCLUSION}

There is intense competition in the era of digitalization and globalization, where there is enormous data roaming. As a result, firms aim to increase their value in the view of their customers while performing their activities. The concept of an audit makes a vital contribution to the realization of these 
objectives. Ensuring continuous control of operations, maintaining and recording of transactions under specific standards provides convenience in achieving the goals.

The internal control system, which reduces the possibility of errors and frauds in the enterprises and aims for efficiency in the resources and ensures compliance with the legal environment, is an absolute must for companies. To establish the system and ensure its effectiveness, companies should make intensive efforts and set targets for this purpose.

The design of the internal control system is the infrastructure to ensure the continuity of the system. When establishing the system, interviews should be made with all departments of the company, job descriptions of all employees should be determined, boundaries should be determined precisely, tasks should be separated, authorities and responsibilities should be determined and all employees should be involved in this process. To ensure the continuity of the system, the employees should get the necessary training. The organization chart should be made according to the structure of the company and the requirements of the sector, and the information and communication systems required by the era should be adopted. The internal control system is a continuous process. Keeping up with the requirements of the period is among the absolute must of the system. To realize this function, risk assessment activities should be carried out continuously and continuous development and training should be provided and qualified personnel needs should be met.

Audit regulation changes in Turkey increased the number of companies that subject to independent audits. This development positively affects the emphasis given to the internal control system. In the independent audit, after the audit agreement was signed, audit firms first look at whether the firm has an effective internal control system or not. Firms with effective internal control tend to regarded as less risky by auditors than firms with an ineffective system. In the valuation of audit risk, control risk is about the effectiveness of the internal control. An effective internal control system is a process that supports the efficacy of independent audits. Low inherent, control and determination risk means low audit risk. In this situation, auditors collect reliable data and based on this data auditors produce reliable reports.

In addition, it is not right to evaluate the control system only by its own standards. Factors such as quality control circles, activities to obtain quality certificates, public disclosure status, and companies that meet the criteria set by independent auditing standards, independent auditing of the companies and regulations of the legal environment positively affect the internal control systems. These factors will enable the firms to compete in environments where there is intense competition. 
This study has some limitations. The main limitation is that only a company in the private sector that produces air springs was involved in the study. Another issue is that the authors were not able to fully include into the ABC Company internal control system. That withholds authors to fully evaluate the effectiveness of the internal control system. In future studies, to generalize the effectiveness of the internal control system, more than one firm of the same sector should be analyzed. Also, by interviewing all the departments, substantial generalizations could be made on the companies. To make international comparisons, companies working in the same sector from different countries can be researched.

\section{REFERENCES}

Akın, S., \& Güngör Tanç, Ş. (2019). İşletmelerde İhracat İşlemleri Sürecinde İç Kontrol Sisteminin Araştırılması. Journal of International Social Research, 12(65), 930-937.

Altunışık, R., Coşkun, R., Bayraktaroğlu, S. \& Yıldırım, E. (2012). Sosyal Bilimlerde Araştırma Yöntemleri (7. Baskı). Sakarya: Sakarya Yayıncılık.

Alvin, A., J. Elder, R. \& S. Beasley, M. (2012). Auditing and Assurance Services. Pearson Prentice Hall. New Jersey.

Arena, M., Arnaboldi \& M., Azzone, G. (2006). Internal audit in Italian organizations: A multiple case study. Managerial Auditing Journal, 21.32, 275-292.

Ashbaugh-Skaife, H., W. Collins, D. \& R. Kinney JR., W. (2006). The discovery and reporting of internal control deficiencies prior to SOXmandated audits. Journal of Accounting and Economics, 44 (1-2), 166-192.

Aslan, Y. (2018). İç Kontrol Ve İç Denetim Mekanizmasinin Gerekliliği: Enron Vakası. Uluslararası Batı Karadeniz Sosyal ve Beşeri Bilimler Dergisi, 2(2), 168-177.

B. Merriam, S. (2009). Qualitative Research: A Guide to Design and Implementation. Jossey-Bass.

Bozkurt, N. (2015). Muhasebe Denetimi (7. Bask1). İstanbul: Alfa.

Bozkurt, N. (2016). Işsletmelerin Kara Deliği: Hile (3. Baskı). İstanbul: Alfa.

Chen, C. J., Su, X. \& Wu, X. (2010).Auditor changes following a Big 4 merger with a local Chinese firm: A case study. Auditing: A journal of practice \& theory, 29(1), 41-72.

CoCo, 1995. CoCo: Guidance on Control. Canadian Cataloguing in Publication Data.

Muhasebe ve Vergi Uygulamaları Dergisi 
Çoşkun, M. F., \& Teraman, Ö. (2018). Etkin Bir İç Kontrol Sistemi Üzerine Nitel Bir Araştırma: Coso Modeli Örneği. Mali Cozum Dergisi/Financial Analysis, (149), 123-143.

Doyle, J., Weili, G. \& McVay, S. (2007). Determinants of Weakness in Internal Control Over Financial Reporting. Journal of Accounting and Economics, 44 (1-2), 193-223.

Efil, İ. (2005). İşletme Organizasyonu (1. Bask1). İstanbul: Aktüel.

Getie Mihret, D. \& Wondim Yismaw, A. (2007). Internal audit effectiveness: an Ethiopian public sector case study. Managerial auditing journal, 22.5, 470-484.

Getie Mihret, D. \& Zemenu Woldeyohannis, G. (2008). Value-added role of internal audit: an Ethiopian case study. Managerial Auditing Journal, 23(6), 567-595.

Gökçen, G., \& Tipi, O. (2019). İşletmelerde Hilelerin Önlenmesine Yönelik İç Kontroller Ve Bist İmalat Sektöründe Bir Araştırma. Marmara Üniversitesi İktisadi ve İdari Bilimler Dergisi, 41(1), 145-169.

Güredin, E. (2010). Denetim ve Güvence Hizmetleri (13th Edition). İstanbul: Türkmen Kitabevi.

http://www.mevzuat.gov.tr.

https://www.governance.co.uk/resources/item/259-the-turnbull-report.

INTOSAI, 2004. Guidelines for Internal Control Standards for the Public Sector.

Kara, M. (2019). Kalite Yönetim Sistemi Belgesine Sahip Olma Durumunun İç Kontrol Sistemine Etkisi. Adlyaman Üniversitesi Sosyal Bilimler Enstitüsü Dergisi, (33), 521-551.

Kaval, H. (2005). Muhasebe Denetimi (2. Bask1). Ankara: Gazi Yayınevi.

Magrane, J. \& Malthus, S. (2010). Audit committee effectiveness: a public sector case study. Managerial Auditing Journal, 25(5), 427-443.

Moeller, R. R. (2004). Sarbanes-Oxley and the New Internal Auditing Rules. John Wiley\&Sons.

Özçetin, N., \& Uzay, Ş. (2019). Süt Üretim İşletmelerinde İç Kontrol Sisteminin Etkinliğinin İncelenmesi: Türkiye Ve Brezilya'daki Süt Üretim İşletmelerinin Karşılaştırılması. Mehmet Akif Ersoy Üniversitesi İktisadi ve İdari Bilimler Fakültesi Dergisi, 5(2), 245-266.

Türkiye İç Denetim Enstitüsü Yayınları (2016). Iç Kontrol - Bütünleşik Çerçeve: Yönetici Özeti. 11 (1). 
Ünkaya, G., \& Dursun, G. D. (2018). İç Kontrol Sisteminin Etkinliği Arttırmada Bilgi İfşası Modelinin Kurulması. Muhasebe ve Denetime Baklş= Accounting \& Auditing Review, 18(55), 15-24.

Yılanc1, M., Yıldı, B. \& Kirac1, M. (2016). Muhasebe Denetimi. Ankara: Detay Yayıncilik.

Yıldırım, A. \& Şimşek, H. (2013). Sosyal Bilimlerde Nitel Araştırma Yöntemleri (9. Baskı). Ankara: Seçkin Yayıncılık.

Zainal, Z. (2007). Case study as a research method. Jurnal Kemanusiaan, (9), 1-6. 